\title{
SYNTHESIS AND CHARACTERIZATION OF NANOSTRUCTURED MATERIALS BASED ON $\mathrm{Fe}_{50} \mathrm{Co}_{50} \mathrm{AND} \mathrm{Fe}_{75} \mathrm{Co}_{25}$
}

\author{
SÍNTESIS Y CARACTERIZACIÓN DE MATERIALES \\ NANOESTRUCTURADOS BASADOS EN Fe ${ }_{50} \mathrm{Co}_{50} \mathbf{Y ~ F e}_{75} \mathrm{Co}_{25}$ \\ SÍNTESE E CARACTERIZAÇÃO DE MATERIAIS \\ NANO-ESTRUTURADOS BASEADOS EM Fe50Co50 E Fe75Co25
}

\author{
Zulia-Isabel Caamaño-De Ávila*, María-Angélica Consuegra-Peñaํ, María-Dolores Baró \\ and Santiago Suriñach ${ }^{2}$ \\ 'Departamento de Física, Universidad del Atlántico, Barranquilla, Atlántico, Colombia \\ ${ }^{2}$ Departamento de Física, Universidad Autónoma de Barcelona, Bellaterra, España \\ e-mail: zuliacaamano@mail.uniatlantico.edu.co
}

(Received: Sep. 14, 2015; Accepted: Nov. 20, 2015)

\section{ABSTRACT}

\begin{abstract}
Towadays, nanostructured magnetic materials are of great interest both in basic research on magnetism and in technological applications. The interest lies in the nanometric particle size, which affects their magnetic properties. Nanostructured magnetic materials based on FeCo have relevant soft magnetic properties, useful in potential applications in information storage equipment and devices. In this paper, nanostructured materials based on $\mathrm{Fe}_{50} \mathrm{CO}_{50}$ and $\mathrm{Fe}_{75} \mathrm{CO}_{25}$ were synthesized using the mechanical alloying method. The influence that the composition and milling time have on the morphology, structure and magnetic properties of nanostructured powders was studied by means of $X$-ray diffraction, Scanning Electron Microscopy (SEM) and Vibrating Sample Magnetometer (VSM). After $30 \mathrm{~h}$ milling, X-ray diffraction results confirmed a body-centred cubic nanostructured $F e$ phase with a crystallite size of about $13.6 \mathrm{~nm}$ for $\mathrm{Fe}_{50} \mathrm{Co}_{50}$ and $22 \mathrm{~nm}$ for $\mathrm{Fe}_{75} \mathrm{CO}_{25}$, and SEM analysis showed the morphology evolution of the powder particles and the lamellar structure. A maximum saturation magnetization $\left(M_{s}\right)$ of $275 \mathrm{emu} / \mathrm{g}$ was obtained for $\mathrm{Fe}_{75} \mathrm{Co}_{25}$ which had been milled for $30 \mathrm{~h}$.
\end{abstract}

Keywords: Mechanical alloying, Magnetic alloy, Nanotechnology, X-ray diffraction, Scanning electron microscopy, Magnetic properties.

How to cite: Caamaño-De Ávila, Z. I., Consuegra-Peña, M. A., Baró, M. D. \& Suriñach, S. (2015). Synthesis and characterization of nanostructured materials based on $\mathrm{Fe}_{50} \mathrm{CO}_{50}$ and $\mathrm{Fe}_{75} \mathrm{CO}_{25}$. CT\&F - Ciencia, Tecnología y Futuro, 6(2), 33-44.

*To whom correspondence should be addressed

+3rd International Meeting for Researchers in Materials \& Plasma Technology - 1st Symposium on Nanoscience and Nanotechnology, Universidad Industrial de Santander and Universidad Pontificia Bolivariana, Colombia, May 4-9, 2015. 


\title{
RESUMEN
}

\begin{abstract}
A ctualmente, los materiales magnéticos nanoestructurados son de gran interés en la investigación básica del magnetismo y en aplicaciones tecnológicas. El interés radica en el tamaño nanométrico de las partículas, lo cual repercute en sus propiedades magnéticas. Los materiales magnéticos nanoestructurados a base de FeCo tienen las mejores propiedades magnéticas blandas, útiles en potenciales aplicaciones en equipos y dispositivos de almacenamiento de información. En este trabajo, se sintetizaron materiales magnéticos nanoestructurados a base de $\mathrm{Fe}_{50} \mathrm{CO}_{50}$ y $\mathrm{Fe}_{75} \mathrm{CO}_{25}$ por el método de aleado mecánico. Se estudió la influencia de la composición y del tiempo de molienda en la morfología, estructura y propiedades magnéticas de los polvos nanoestructurados por medio de la difracción de rayos X, Microscopía Electrónica de Barrido (SEM) y Magnetometría de Muestra Vibrante (VSM). Los resultados de difracción de rayos $X$ confirmaron la fase nanoestructurada de Fe cúbica centrada en el cuerpo con un tamaño de cristalito cerca de $13.6 \mathrm{~nm}$ para el $\mathrm{Fe}_{50} \mathrm{CO}_{50}$ y de $22 \mathrm{~nm}$ para el $\mathrm{Fe}_{75} \mathrm{Co}_{25}$ después de 30 h de molienda, y el análisis por SEM mostró la evolución de la morfología de las partículas de polvo y la estructura laminar. Se obtuvo una magnetización de saturación $\left(M_{s}\right)$ máxima de 275 emu/g para el $\mathrm{Fe}_{75} \mathrm{CO}_{25}$ molido $30 \mathrm{~h}$.
\end{abstract}

Palabras clave: Aleamiento mecánico, Aleación magnética, Nanotecnología, Difracción de rayos X, Microscopía electrónica de barrido, Propiedades magnéticas.

\section{RESUMO}

\begin{abstract}
A tualmente, os materiais magnéticos nano-estruturados são de grande interesse para a pesquisa básica do magnetismo e em aplicações tecnológicas. $\bigcirc$ interesse radica no tamanho nanométrico das partículas, sendo que o tamanho repercute em suas propriedades magnéticas. Os materiais magnéticos nano-estruturados a base de FeCo contam com as melhores propriedades magnéticas brandas, úteis em potenciais aplicações em equipamentos e dispositivos de armazenagem de informação. Neste trabalho, sintetizamos materiais magnéticos nano-estruturados a base de $\mathrm{Fe}_{50} \mathrm{Co}_{50}$ y $\mathrm{Fe}_{75} \mathrm{Co}_{25}$ pelo método de ligação mecânica. Estudou-se a influência da composição e do tempo de moagem na morfologia, estrutura e propriedades magnéticas dos pós nano-estruturados por meio da difração dos raios $X$, Microscopia Eletrônica de Barrido (SEM) e Magnetometria de Amostra Vibrante. Os resultados da difração de raios $X$ confirmaram a fase nano-estruturada de Fe cúbica centrada no corpo com um tamanho de cristalito de aproximadamente $13.6 \mathrm{~nm}$ para $\circ \mathrm{Fe}_{50} \mathrm{Co}_{50}$ e de $22 \mathrm{~nm}$ para $\circ \mathrm{Fe}_{75} \mathrm{Co}_{25}$, depois de $30 \mathrm{~h}$ de moagem, e a análise por SEM mostrou a evolução da morfologia das partículas de pó e a estrutura laminar. Obteve-se uma magnetização de saturação $\left(M_{s}\right)$ máxima de 275 emu/g para o $\mathrm{Fe}_{75} \mathrm{Co}_{25}$ moído $30 \mathrm{~h}$.
\end{abstract}

Palavras-chave: Ligação mecânica, Ligação magnética, Nanotecnologia, Difração de raios X, Microscopia eletrônica de barrido, Propriedades magnéticas. 


\section{INTRODUCTION}

Over the last decades, nanostructured materials have been widely studied as they have shown new physical, mechanical and chemical properties when compared to the coarse-grained polycrystalline materials (Akkouche et al., 2011; Bergheul, Otmane \& Azzaz, 2012).

In particular, nanostructured $\mathrm{Fe}$-Co alloys display interesting soft magnetic properties, such as high permeability, high Curie temperature and the highest saturation magnetization of all known magnetic materials (Khajepour \& Sharafi, 2011; Chermahini, Rahimipour \& Pakseresht, 2014). Although Fe-Co alloys exhibit soft magnetic properties in the vicinity of $\sim 30$ at. \% Co concentration (Sharifati \& Sharafi, 2012) and equiatomic composition (Khajepour \& Sharafi, 2011), they can be further enhanced by microstructure refinement (Sharifati \& Sharafi, 2012). All these notable soft magnetic properties make these nanostructured materials useful in a wide variety of technological and industrial applications (Khajepour \& Sharafi, 2011; Bergheul et al., 2012; Yousefi \& Sharafi, 2012; Chermahini et al., 2014).

In the search for synthesis methods of nanostructured magnetic alloys, Mechanical Alloying (MA) is one of the most commonly used methods, because it is relatively inexpensive and easy to handle and scale up for future technological applications. The obtained nanostructured powders can then be compacted in a great variety of desired shapes and sizes, which would not be possible with other kinds of conventional synthesis methods (Akkouche et al., 2011; Khajepour \& Sharafi, 2011; Bergheul et al., 2012; Sharifati \& Sharafi, 2012; Yousefi \& Sharafi, 2012).

In this study, the synthesis of nanostructured $\mathrm{Fe}_{50} \mathrm{Co}_{50}$ and $\mathrm{Fe}_{75} \mathrm{Co}_{25}$ alloys has been achieved by mechanical alloying, presenting the evolution of microstructure and magnetic properties over different milling times (7.5, 15 and $30 \mathrm{~h})$.

\section{EXPERIMENTAL PROCEDURE}

In the present study binary $\mathrm{Fe}$-Co powder alloys with nominal compositions $\mathrm{Fe}_{50} \mathrm{Co}_{50}$ and $\mathrm{Fe}_{75} \mathrm{Co}_{25}$ were mechanically alloyed in high energy ball milling Spex
$8000 \mathrm{mix} / \mathrm{mill}$. The elemental powders of $\mathrm{Fe}$ (99.5 \%, 6-9 $\mu \mathrm{m})$ and $C o(99.8 \%, 2 \mu \mathrm{m})$ were accurately weighted to obtain the desired compositions. The mixture of the powders with one stainless steel ball was charged into a stainless steel container under $A r$ atmosphere inside a glove box. The mechanical alloying was performed at room temperature using a milling intensity of $825 \mathrm{rpm}$, a ball to powder mass ratio of $1: 1$ and milling times of 7.5, 15, and $30 \mathrm{~h}$. The milling was stopped every 100 minutes to avoid overheating.

Morphological, microstructural and compositional studies were also conducted on slightly polished, embedded alloyed powder particles by means of scanning electron microscopes (FESEM Merlin Zeiss microscopes) coupled with Energy Dispersive X-ray analysis (EDX).

Structural characterization was performed on a Phillips X'Pert diffractometer. XRD analysis was carried out at room temperature, using $\mathrm{Cu}$ radiation over $30-120^{\circ} 2 \theta$ and $0.02^{\circ} / 8$ s step. XRD patterns for milled samples at 7.5, 15 and $30 \mathrm{~h}$ were obtained. The mean crystallite size, phase crystalline percentage, lattice parameter and micro strains were estimated by diffraction peaks refinement software MAUD (Material Analysis Using Diffraction) (Lutteroti \& Scardi, 1990).

Magnetic hysteresis curves were recorded on an Oxford Instruments VSM, in order to study the magnetic properties of saturation magnetization and coercive field of milled powders. All measurements were performed at room temperature with an applied magnetic field of one Tesla.

\section{RESULTS}

\section{Morphological Characterization by SEM}

Figure 1 shows the morphological evolution of $\mathrm{Fe}_{50} \mathrm{Co}_{50}$ alloy as a function of milling time (0, 7.5, 15 and $30 \mathrm{~h}$ ). In Figure 1a, the different shapes of the alloying elements particles for the un-milled powder can be seen. The Co particles have spherical shape while the $\mathrm{Fe}$ particles have cylindrical shape. In Figure 1b, the formation of $\mathrm{Fe}$ and $\mathrm{Co}$ particles agglomerates with flattened shape can be observed for $7.5 \mathrm{~h}$ milling time compositions, due to the collisions that occur during the milling process. 
SEM micrographs for the powders milled $15 \mathrm{~h}$ are shown in Figure 1c. Aggregates of powder particles can be seen, as a result of the flattening, welding, fracture and rewelding of powders, which is a typical feature of the mechanical alloying process for ductile-ductile systems, as reported in the literature (Zeng et al., 2007; Chermahini et al., 2009a; Chermahini et al., 2009b; Shokrollahi, 2009; Akkouche et al., 2011; Chitsazan et al., 2011; Yepes et al., 2014).

A narrower distribution of particle size can be observed as compared to the samples milled for $7.5 \mathrm{~h}$, as previously reported by Chermahini et al. (2009a) for powders of similar compositions.

The continuous cold welding and fracture events evidenced by the refinement of powders particles can be seen in SEM microphotographs of the alloy milled for $30 \mathrm{~h}$, as shown in Figure 1d. The decrease in size of aggregates particles as the milling time increases is characteristic of the milling process. All the observations for $\mathrm{Fe}_{50} \mathrm{Co}_{50}$ agree with those obtained for the same composition milled for 8, 20 and 35 h (Yepes et al., 2014).

Figures 2 and 3 show SEM micrographs for the $\mathrm{Fe}_{50} \mathrm{Co}_{50}$ and $\mathrm{Fe}_{75} \mathrm{Co}_{25}$ 7.5, 15 and $30 \mathrm{~h}$ milled alloys. The lamellar structure of the aggregates of $\mathrm{Fe}$ and $\mathrm{Co}$ particles for both compositions can be seen, which is characteristic of the milling process of ductileductile elements, as reported in precedent studies (Suryanarayana, 2001; Chermahini et al., 2009a).

Magnified SEM in Figure 2a at $7.5 \mathrm{~h}$ of milling shows clear and dark layers nearly in equal proportion, which evidences the concentration of $\mathrm{Fe}$ and $\mathrm{Co}$. At 15 $\mathrm{h}$ of milling, a lower proportion of clear, mostly linear layers is observed, as shown in the magnified SEM of Figure 2b. At $30 \mathrm{~h}$ of milling, the separations between layers cannot be observed and the elements of the alloy

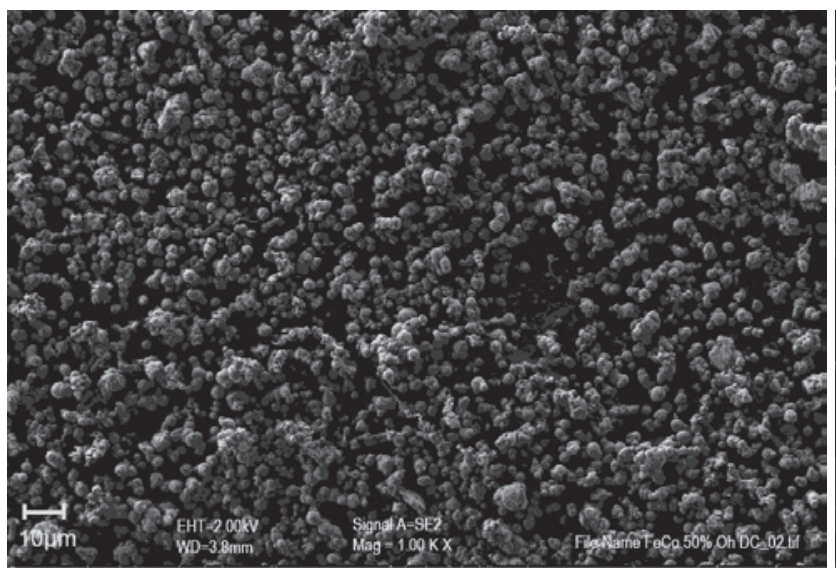

(a)

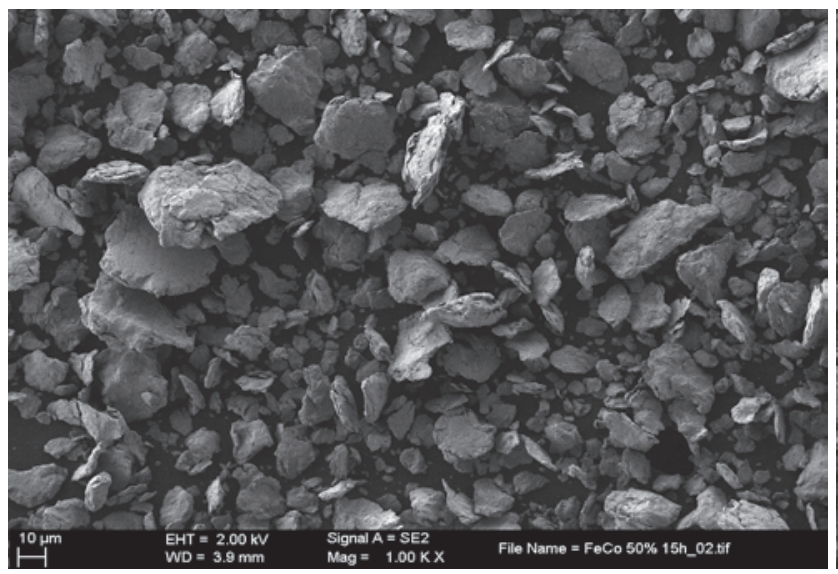

(c)

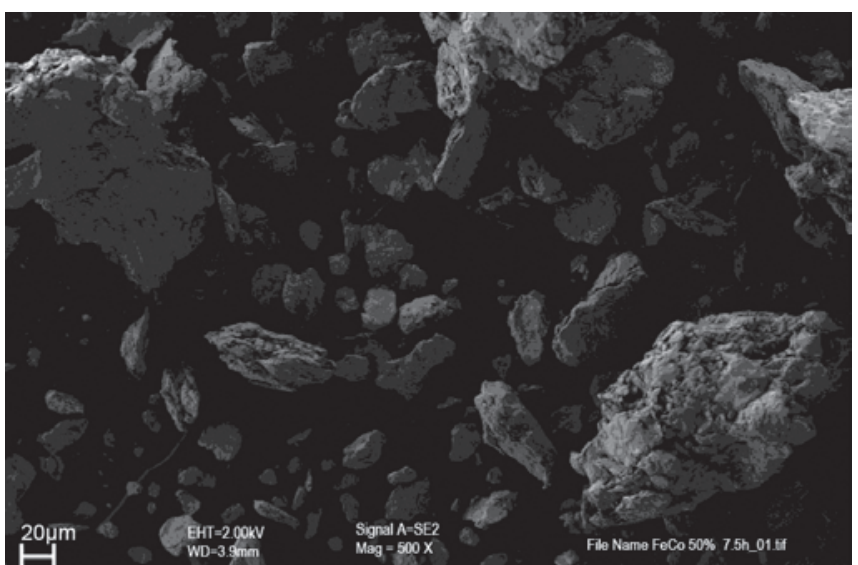

(b)

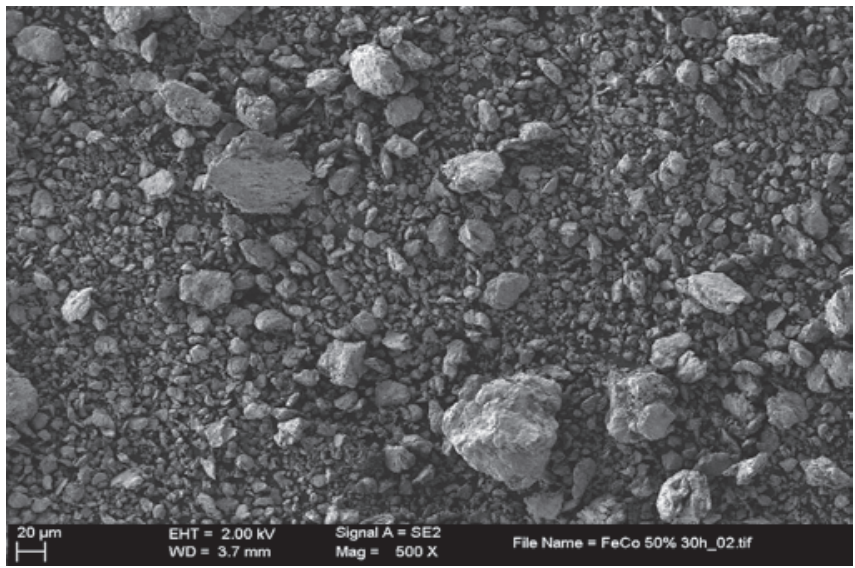

(d)

Figure 1. SEM micrographs of $\mathrm{Fe}_{50} \mathrm{CO}_{50}$ for different milling times: (a) $0 \mathrm{~h}$ (un-milled), (b) $7.5 \mathrm{~h}$, (c) $15 \mathrm{~h}$ and (d) $30 \mathrm{~h}$. 


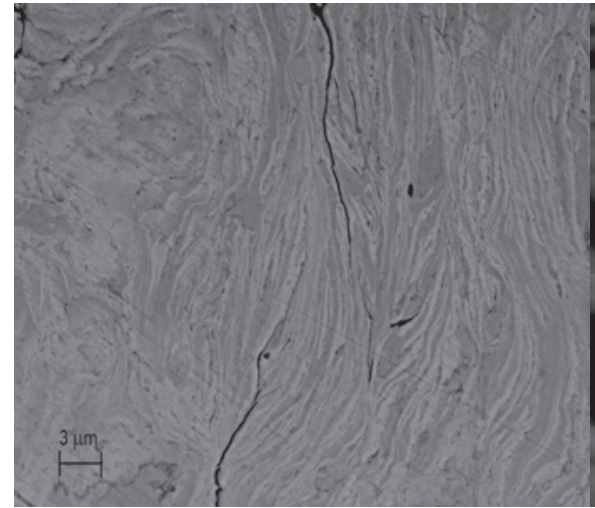

(a)

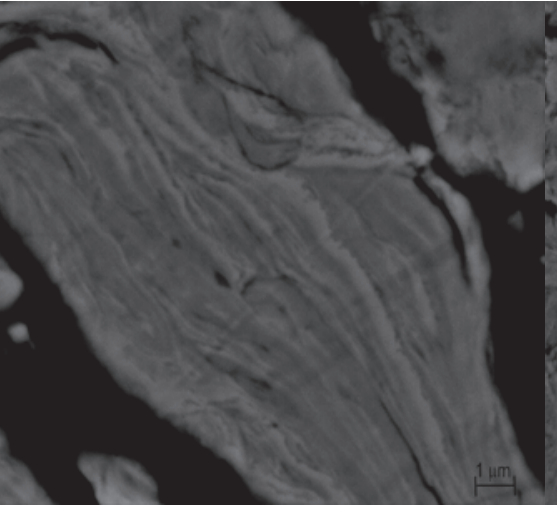

(b)

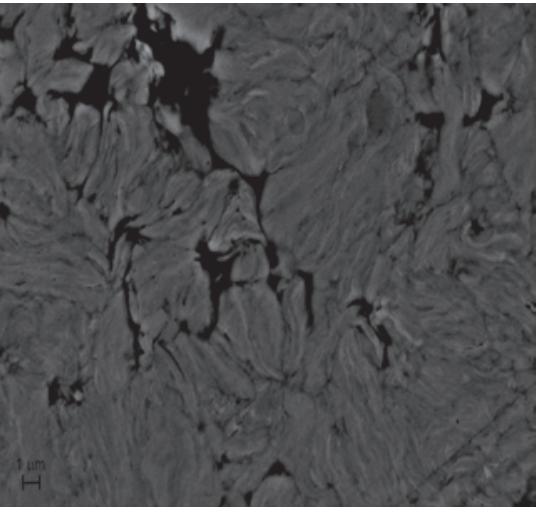

(c)

Figure 2. Magnified SEM images of the Fe ${ }_{50} \mathrm{Co}_{50}$ alloys powder for different milling times: (a) $7.5 \mathrm{~h}$, (b) $15 \mathrm{~h}$, and (c) $30 \mathrm{~h}$.

cannot be identified. Also, Figure 2c shows the random welding of the powder particles sizes, resulting in a lamellar structure, which indicates the segregation of $\mathrm{Co}$ atoms and the formation of the alloy. Analogue results were reported by Bergheul et al. (2012) for powders of composition $\mathrm{Fe}_{60} \mathrm{Co}_{40}$ milled for 12 and $36 \mathrm{~h}$.

For 7.5 h milling times, Figure 3a, clear and dark layers can be distinguished, corresponding to the phases of the alloying elements. In the figure, the darker layer predominates as opposed to the alloy of composition $\mathrm{Fe}_{50} \mathrm{Co}_{50}$, due to the higher concentration of $\mathrm{Fe}(75 \%)$ in this alloy (darker layer). Magnified SEM in Figure 3b for the alloy $\mathrm{Fe}_{75} \mathrm{Co}_{25}$ milled $15 \mathrm{~h}$, clear layers cannot be observed as they were observed for the sample $\mathrm{Fe}_{50} \mathrm{Co}_{50}$. This indicates that $\mathrm{Co}$ diffusion for $\mathrm{Fe}_{75} \mathrm{Co}_{25}$ is higher than for $\mathrm{Fe}_{50} \mathrm{Co}_{50}$ alloy, because $\mathrm{Co}$ concentration is lower and it can be faster diffused, occupying $\mathrm{Fe}$ atoms places easily. At $30 \mathrm{~h}$ of milling, the distance between layers decreases, causing a higher diffusion of $\mathrm{Co}$, so it can be said that a solid solution is formed (Figure 3c). Similar results were reported in literature by Bergheul et al. (2012) and Chermahini et al. (2014).

Figures 4 and 5 show the maps of $\mathrm{Fe}$ and $\mathrm{Co}$ distributions for the selected areas of samples $\mathrm{Fe}_{50} \mathrm{Co}_{50}$ and $\mathrm{Fe}_{75} \mathrm{CO}_{25}$ milled $7.5 \mathrm{~h}$ and $15 \mathrm{~h}(\mathrm{FeK} \alpha 1$ and $\mathrm{CoK} \alpha 1$ images), respectively.

In both Figures, white and black zones corresponding to $\mathrm{Fe}$ and $\mathrm{Co}$ can be seen. For $7.5 \mathrm{~h}$ milling time, as shown in Figures $4 \mathrm{a}$ and 5a, it is difficult to distinguish between the two types of particles ( $\mathrm{Fe}$ and $\mathrm{Co}$ ); this indicates that the mixture of $\mathrm{Fe}$ and $\mathrm{Co}$ has begun. Nevertheless, at $15 \mathrm{~h}$ of milling (Figures $4 \mathrm{~b}$ and $5 \mathrm{~b}$ ), a narrower distribution between $\mathrm{Fe}$ and $\mathrm{Co}$ for $\mathrm{Fe}_{75} \mathrm{CO}_{25}$ is observed, which reveals the formation of a FeCo solid solution, in comparison with the alloy $\mathrm{Fe}_{50} \mathrm{Co}_{50}$ milled at the same time, where a solid solution is just beginning.

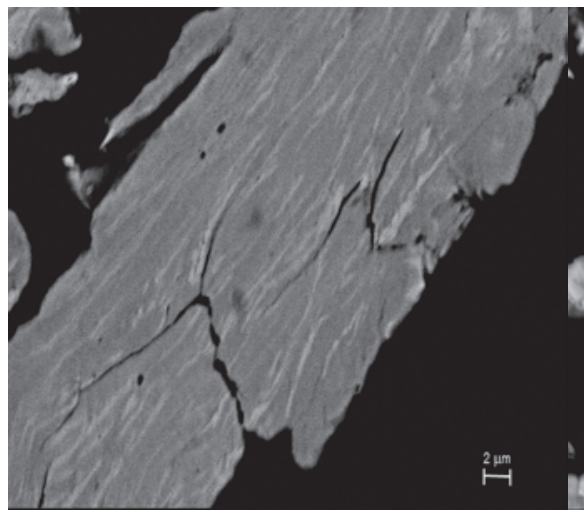

(a)

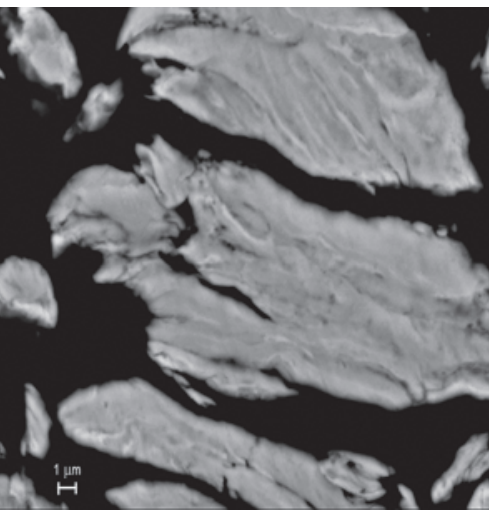

(b)

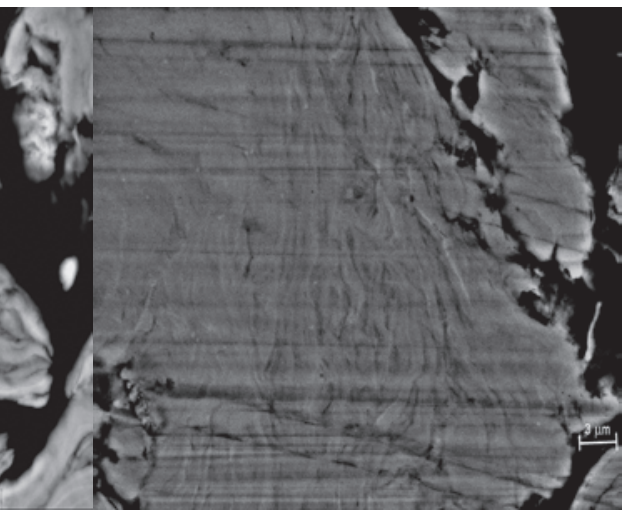

(c)

Figure 3. Magnified SEM images of the $\mathrm{Fe}_{75} \mathrm{Co}_{25}$ alloys powder for different milling times: (a) $7.5 \mathrm{~h}$, (b) $15 \mathrm{~h}$ and (c) $30 \mathrm{~h}$. 


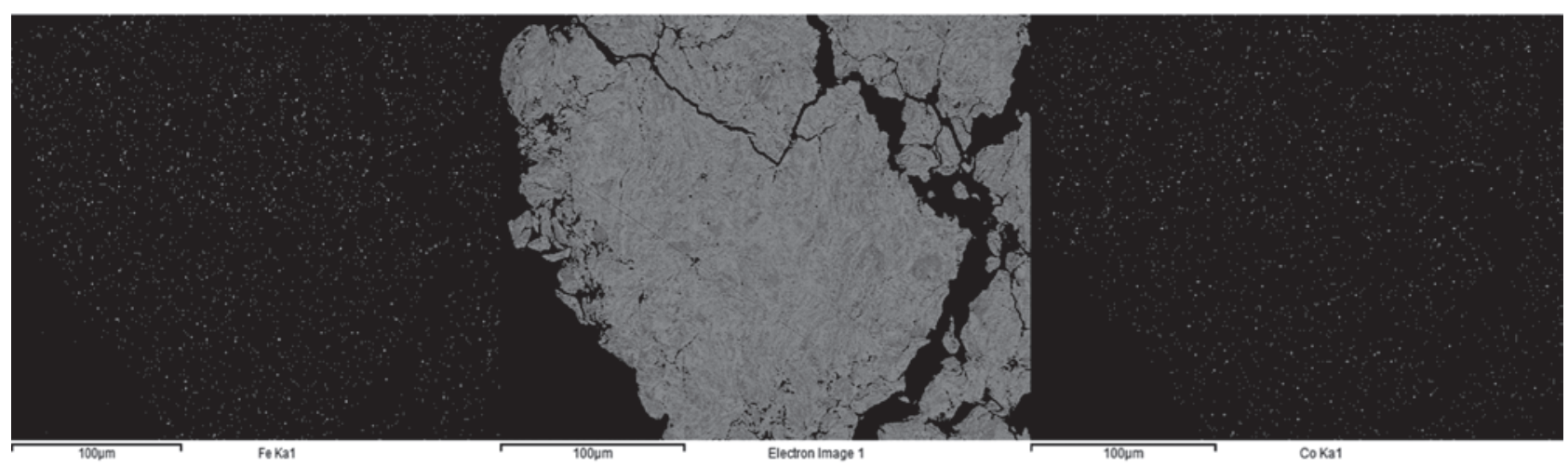

(a)

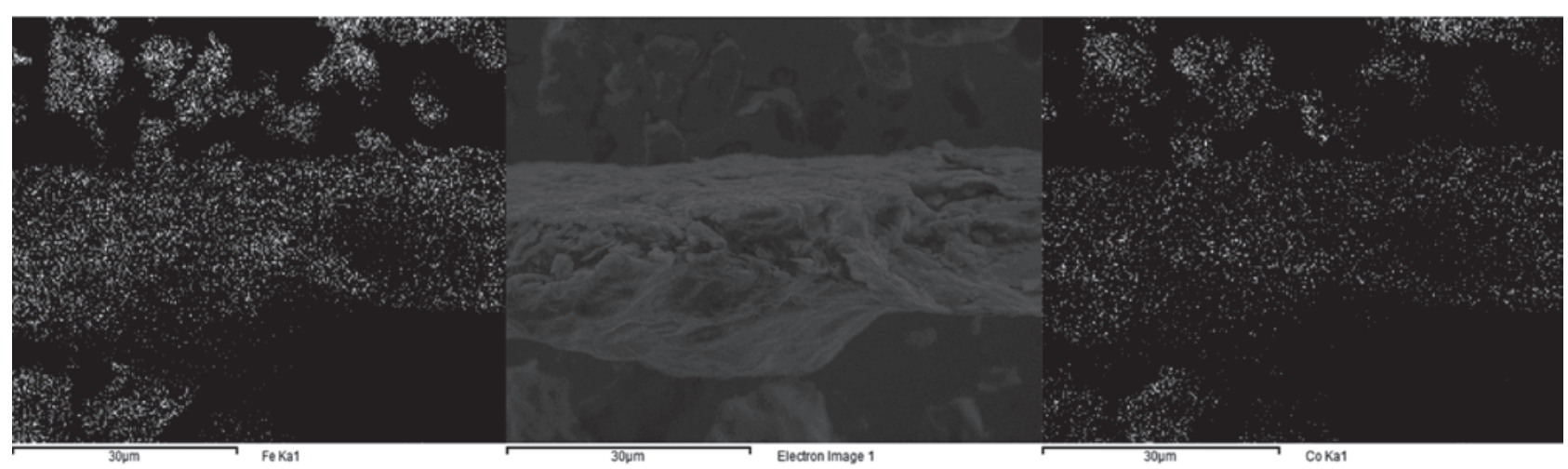

(b)

Figure 4. Maps of $\mathrm{Fe}$ and $\mathrm{Co}$ distributions of the sample $\mathrm{Fe}_{50} \mathrm{Co}_{50}$ milled: (a) $7.5 \mathrm{~h}$ and (b) $15 \mathrm{~h}$.

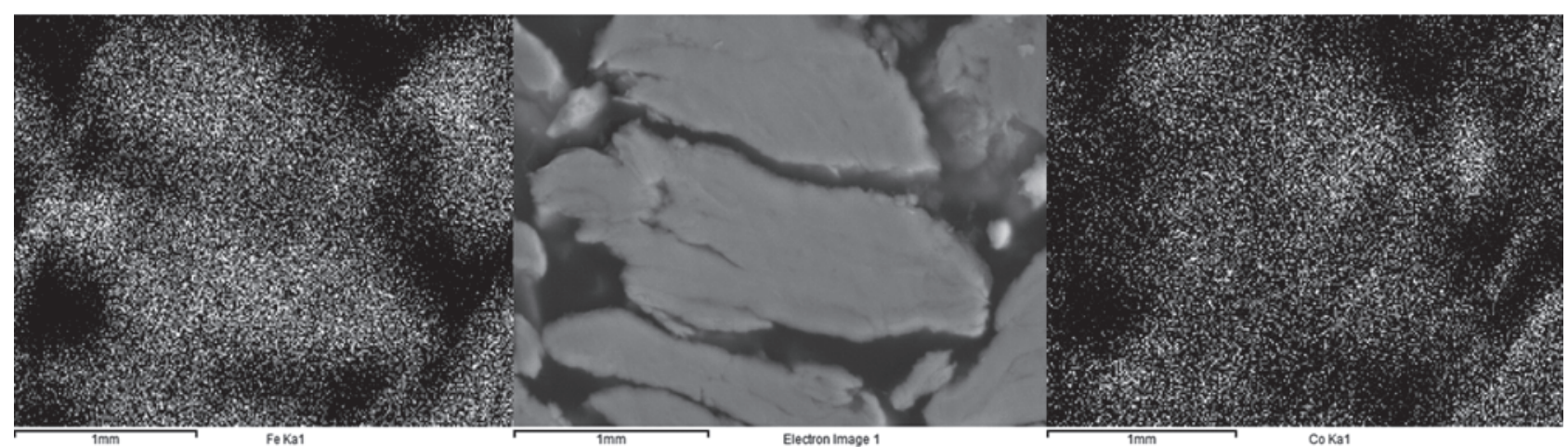

(a)

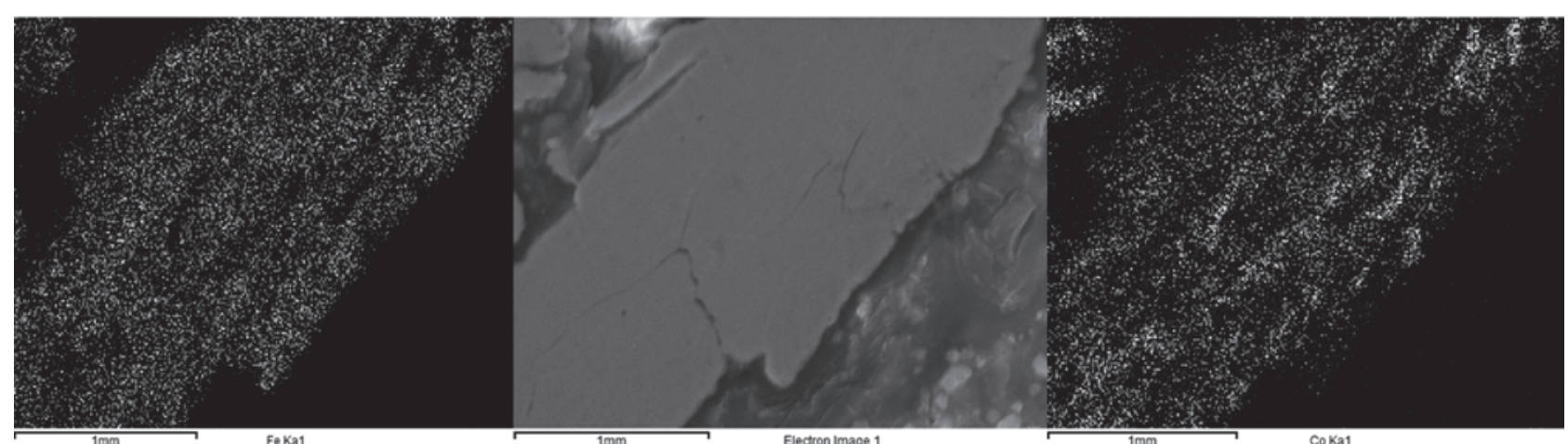

(b)

Figure 5. Maps of $\mathrm{Fe}$ and $\mathrm{Co}$ distributions of the sample $\mathrm{Fe}_{75} \mathrm{Co}_{25}$ milled: a) $7.5 \mathrm{~h}$ and b) $15 \mathrm{~h}$. 
A similar behavior was reported by Akkouche et al. (2011) for the $\mathrm{Fe}_{50} \mathrm{Co}_{50}$ milled $100 \mathrm{~h}$ and $200 \mathrm{~h}$.

\section{Characterization by XRD}

Figure 6 shows the evolution of the XRD patterns for $\mathrm{Fe}_{50} \mathrm{Co}_{50}$ and $\mathrm{Fe}_{75} \mathrm{Co}_{25}$ alloys as a function of the milling time. In Figure 6a, for the unmilled powders of $\mathrm{Fe}_{50} \mathrm{Co}_{50}(\mathrm{O} \mathrm{h}$ ), the presence of $\mathrm{Fe}$ (bcc), Co (fcc) and Co (hcp) is confirmed. From 7.5 h of milling, Co phases disappear, as the $\mathrm{Fe}$ phase remains, and an observable broadening of the bcc $\mathrm{Fe}$-Co diffraction peaks occurs due to the deformation processes (at macroscopic level) and internal stresses during the milling process. This behavior is attributed to the diffusion of $\mathrm{Co}$ atoms into the $\mathrm{Fe}$ bcc lattice, as it was reported by Chermahini et al. (2009a; 2009b).

Figure 6b presents the XRD patterns for $\mathrm{Fe}_{75} \mathrm{Co}_{25}$ milled at different times. The same behavior of Figure $6 \mathrm{a}$ is observed here, as the milling time increases, Co phases disappear. However, for the $\mathrm{Fe}_{50} \mathrm{Co}_{50}$ alloy, $\mathrm{Co}$ diffraction peaks are more broadened than for $\mathrm{Fe}_{75} \mathrm{Co}_{25}$ alloy, indicating that the equiatomic composition has a lower crystallite size than that of $\mathrm{Fe}_{75} \mathrm{Co}_{25}$. Figure 7 shows the variation of the crystallite size, lattice

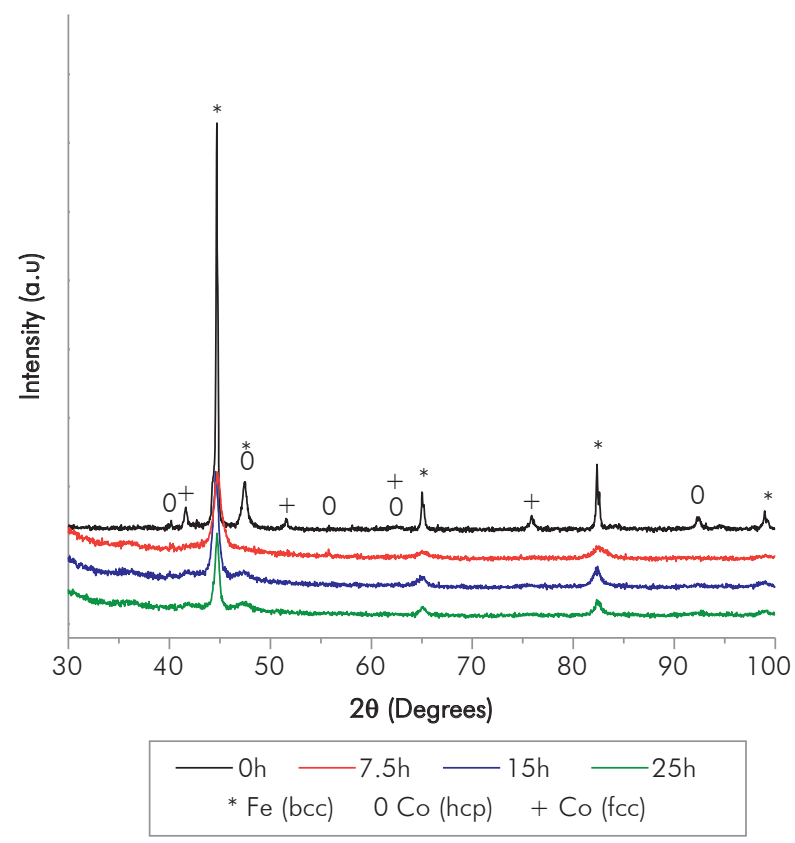

(a) parameter and phase percentage of $\mathrm{Fe}$ and $\mathrm{Co}$ for $\mathrm{Fe}_{50} \mathrm{Co}_{50}$ and $\mathrm{Fe}_{75} \mathrm{Co}_{25}$ alloys, respectively.

The values for the crystallite size, lattice parameter and phase percentages of $\mathrm{Fe}$ and $\mathrm{Co}$ for both alloys were calculated from the diffraction peaks refinement Maud software.

From Figure $7 \mathrm{a}$, it could be observed that the crystallite size decreased from a value of $173.7 \mathrm{~nm}$ at 0 $\mathrm{h}$ down to a value of $13.6 \mathrm{~nm}$ at $30 \mathrm{~h}$ of milling for the $\mathrm{Fe}$ phase. These results differ from the values reported by Yepes et al. (2014) who found a crystallite size of $7.5 \mathrm{~nm}$ at $35 \mathrm{~h}$ of milling. The difference between these values could result from the experimental conditions used for the mechanical alloying process of the powders. Nevertheless, these values are similar to those reported in the literature for the same composition (Zeng et al., 2007; Chermahini et al., 2009a; Chermahini et al., 2009b; Shokrollahi, 2009; Akkouche et al., 2011; Chitsazan et al., 2011; Khajepour \& Sharafi, 2011; Bergheul et al., 2012; Yousefi \& Sharifati, 2012; Chermahini et al., 2014).

For the hcp Co phase, crystallite size values of 28.5 $\mathrm{nm}$ at $0 \mathrm{~h}$ until $3.4 \mathrm{~nm}$ at $30 \mathrm{~h}$ of milling were obtained, which corroborates the reduction of the crystallite size of Co with increased milling time.

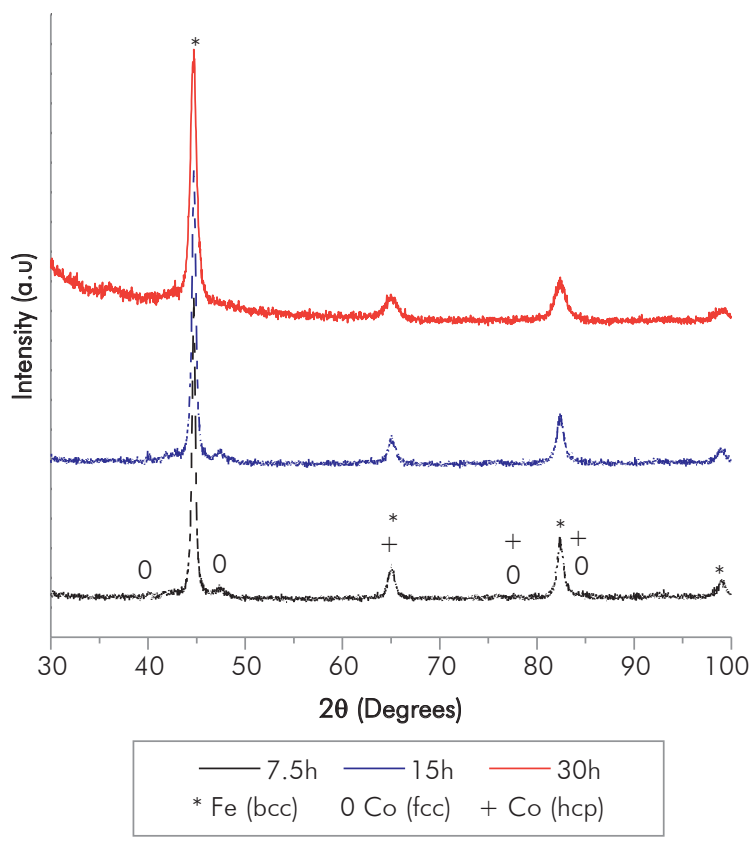

(b)

Figure 6. (a) XRD patterns of $\mathrm{Fe}_{50} \mathrm{Co} 050$ for $0 \mathrm{~h}$ (unmilled powders), $7.5 \mathrm{~h}, 15 \mathrm{~h}$ and $25 \mathrm{~h}$. (b) XRD patterns of $\mathrm{Fe}_{75} \mathrm{Co}_{25}$ for $7.5 \mathrm{~h}, 15 \mathrm{~h}$ and $25 \mathrm{~h}$. 


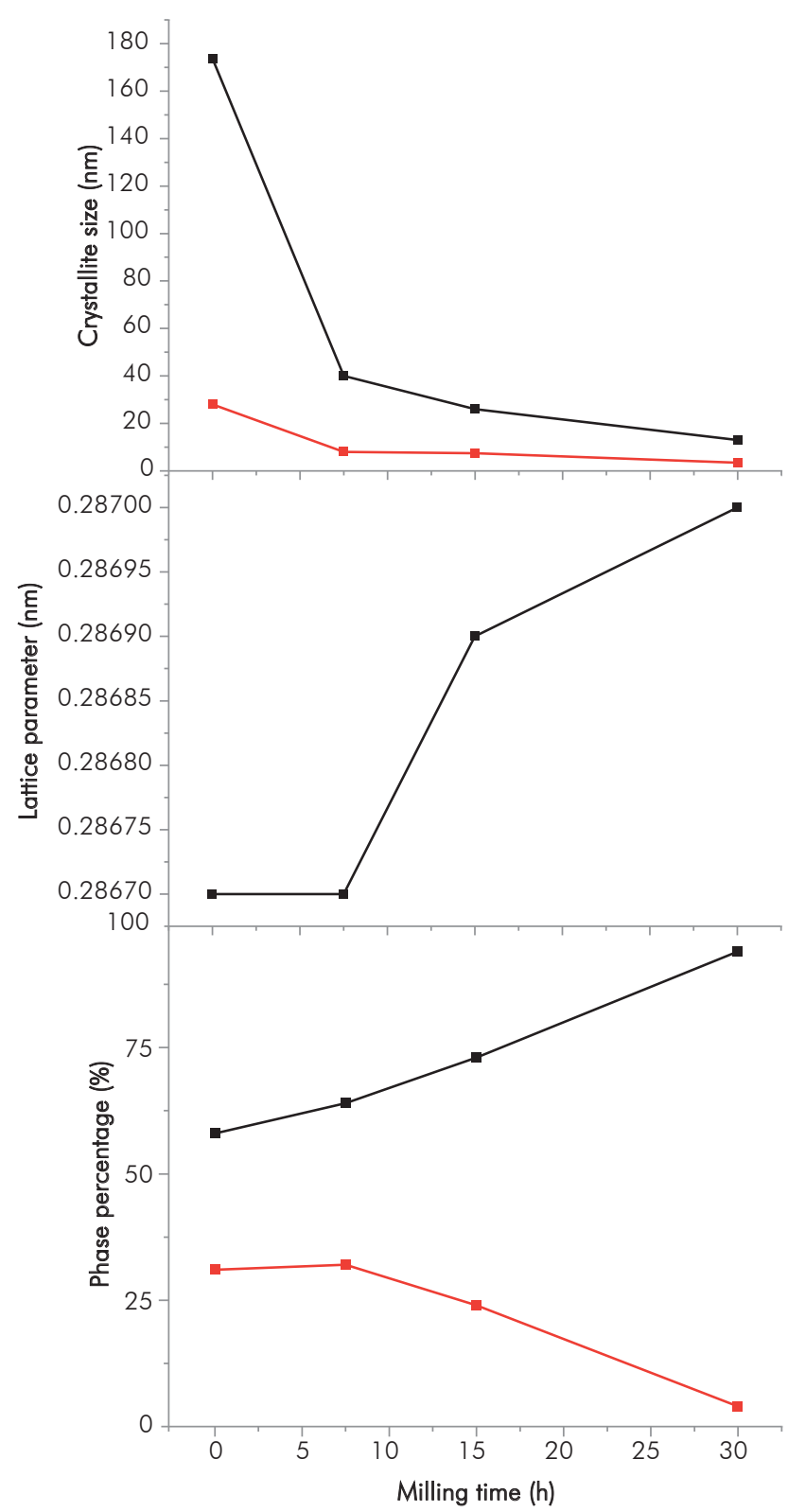

(a)

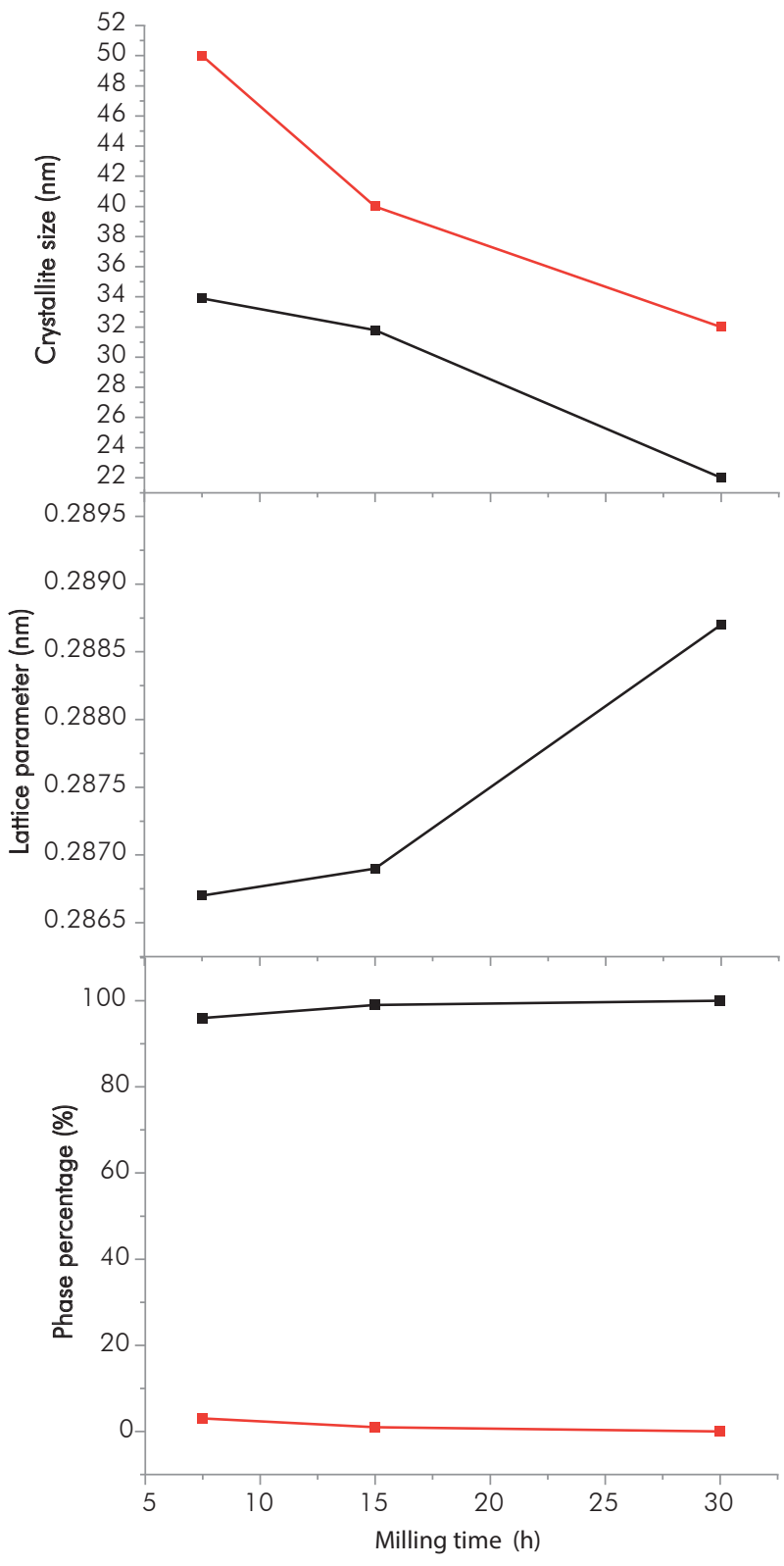

(b)

Figure 7. Crystallite size, lattice parameter and phase percentage of $\mathrm{Fe}$ and $\mathrm{Co}$ as a function of milling time for: (a) $\mathrm{Fe}_{50} \mathrm{CO}_{50}$ and (b) $\mathrm{Fe}_{75} \mathrm{CO}_{25}$.

From Figure 7b, corresponding to the crystallite size for the sample $\mathrm{Fe}_{75} \mathrm{Co}_{25}$ milled at various times, it can be noticed that the crystallite size decreases from a value of $33.9 \mathrm{~nm}$ at $7.5 \mathrm{~h}$ to a value of $22 \mathrm{~nm}$ at $30 \mathrm{~h}$ of milling for the $\mathrm{Fe}$; and for the $\mathrm{Co}$, crystallite size values from 50.4 $\mathrm{nm}$ at $7.5 \mathrm{~h}$ up to $32 \mathrm{~nm}$ at $30 \mathrm{~h}$ of milling are observed.
In Figures $7 \mathrm{a}$ and $7 \mathrm{~b}$ it is observed that the lattice parameter tends to increase with the milling time for the two studied compositions. This behavior differs from that reported in the literature (Zeng et al., 2007; Chermahini et al., 2009a; Chermahini et al., 2009b; Shokrollahi, 2009; Akkouche et al., 2011; Chitsazan et al., 2011; Khajepour \& Sharafi, 2011; Bergheul et 
al., 2012; Sharifati \& Sharafi, 2012; Yousefi \& Sharafi, 2012; Chermahini et al., 2014), in which the lattice parameter decreases as milling time increases. The increase of the lattice parameter observed in this work could be due to:

- The substantial amount of Co atoms segregated into grain boundaries, which contain high amount of vacancies, dislocations, impurities and other defects that become, suitable places for $C o$ atoms segregation (Chermahini et al., 2014).

- As the volume fraction of grain boundaries increases, some compressive and tensile force on the interfaces and lattice may appear, which can increase lattice parameter (Chermahini et al., 2014).

From Figure 7a and $7 \mathrm{~b}$ it is also seen that, as milling time increases, the $\mathrm{Co}$ phase decreases while the $\mathrm{Fe}$ phase increases, which confirms the formation of $\mathrm{Fe}$ (Co) solid solution for both compositions. Nevertheless, for the sample $\mathrm{Fe}_{75} \mathrm{Co}_{25}$, the $\mathrm{Fe}$ phase percentage slightly changes (from 96.1 to $100 \%$ ), unlike the $\mathrm{Fe}$ phase percentage for the sample $\mathrm{Fe}_{50} \mathrm{Co}_{50}$, which changes from $64.5 \%$ to $94.5 \%$. These results indicate that for the $\mathrm{Fe}_{75} \mathrm{Co}_{25}$ alloy the solid solution at $30 \mathrm{~h}$ of milling is completely formed, while for $\mathrm{Fe}_{50} \mathrm{Co}_{50}$ alloy the solid solution is not yet completed. XRD results are consistent with the SEM results for the alloys milled at different times.

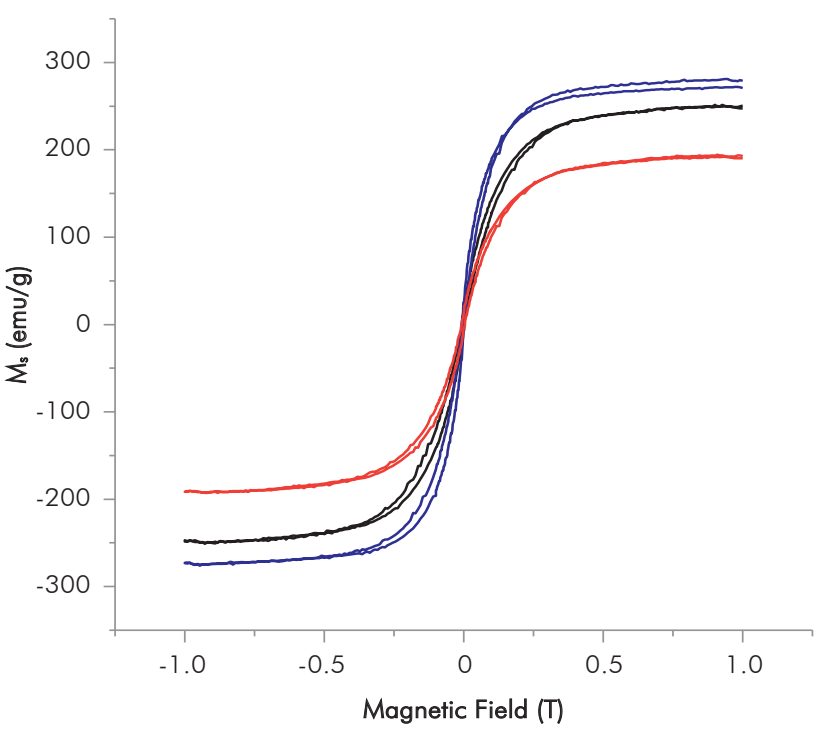

(a)

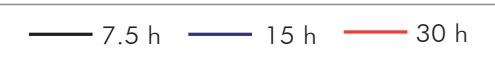

Figure 8. Magnetic hysteresis curves of the (a) $\mathrm{Fe}_{50} \mathrm{Co}_{50}$ and (b) $\mathrm{Fe}_{75} \mathrm{Co}_{25}$ powders milled at various milling times.

\section{Characterization by VSM}

Figure 8 shows the magnetic hysteresis curves of the $\mathrm{Fe}_{50} \mathrm{CO}_{50}$ and $\mathrm{Fe}_{75} \mathrm{Co}_{25}$ milled at different times. For the $\mathrm{Fe}_{50} \mathrm{Co}_{50}$ (Figure 8a), an increase of saturation magnetization is observed with at milling time of 7.5 and $15 \mathrm{~h}$; however, saturation magnetization decreases at $30 \mathrm{~h}$ of milling. In the meantime, for the $\mathrm{Fe}_{75} \mathrm{Co}_{25}$ alloy (Figure 8b), the highest saturation magnetization (275 emu/g) was obtained for the sample milled for 30 $\mathrm{h}$. This value is higher than those obtained by Yousefi and Sharafi (2012) and Poudyal et al. (2012) for a similar composition milled for $40 \mathrm{~h}$ (200 emu/g) and $20 \mathrm{~h} \mathrm{(240}$ emu/g), respectively.

The magnetization increase is related to the decrease of the crystallite size at higher milling times and with the diffusion of $\mathrm{Co}$ atoms in the crystalline lattice of $\mathrm{Fe}$, allowing the homogeneity of the alloy.

\section{CONCLUSIONS}

- Nanostructured alloys of $\mathrm{Fe}_{75} \mathrm{Co}_{25}$ and $\mathrm{Fe}_{50} \mathrm{Co}_{50}$ were synthesized by the high energy mechanical alloying method for milling times of 7.5, 15 and $30 \mathrm{~h}$.

- The evolution of the crystallite size and the lattice parameter as a function of the milling time was evidenced by XRD. After $30 \mathrm{~h}$ of milling a coherent

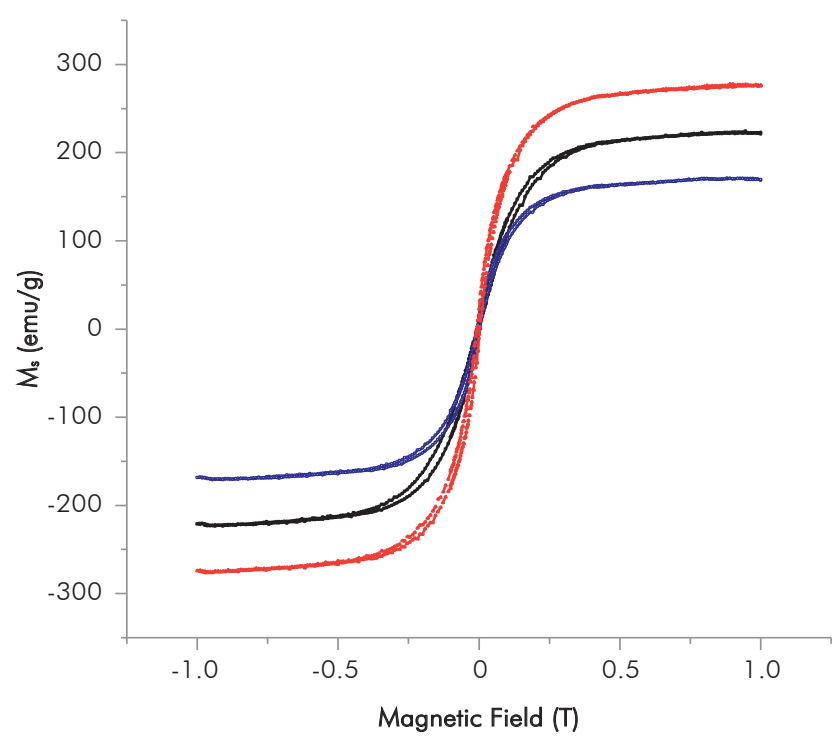

(b) 
domain diffraction of 13 and $22 \mathrm{~nm}$ was obtained for the $\mathrm{Fe}_{50} \mathrm{Co}_{50}$ and $\mathrm{Fe}_{75} \mathrm{Co}_{25}$ alloys respectively. As the crystallite size decreases, the lattice parameter increases, probably due to the substitution of $\mathrm{Co}$ atoms into the $\mathrm{Fe}$ crystalline lattice.

- Morphological study by SEM showed fracture and welding of the initials particles with the milling time for both compositions. Also, the lamellar structure, which is characteristic of the ductile-ductile systems, was evidenced by magnification SEM images.

- The evolution of powders morphology, as well as the crystallite size and lattice parameter, are attributed to the deformation processes that powders undergo when they are mechanically alloyed within a high energy ball milling.

- SEM, EDX and XRD results confirm the formation of the $\mathrm{Fe}(\mathrm{Co})$ solid solution in both compositions of study. For the alloy $\mathrm{Fe}_{50} \mathrm{Co}_{50}$, the solid solution was formed at $30 \mathrm{~h}$ of milling, while for the $\mathrm{Fe}_{75} \mathrm{Co}_{25}$ alloy, the solid solution was formed at $15 \mathrm{~h}$ of milling, indicating that the concentration of $\mathrm{Co}$ in the alloy promote the formation of the solid solution of $\mathrm{Co}$ in $\mathrm{Fe}$.

- A maximum saturation magnetization value of 275 emu/g was obtained for the $\mathrm{Fe}_{75} \mathrm{Co}_{25}$ sample at $30 \mathrm{~h}$ of milling from the magnetic hysteresis curves by VSM; until now, this is the highest value of saturation magnetization of $\mathrm{Fe}$-Co alloys.

\section{ACKNOWLEDGMENTS}

To Universidad del Atlántico (Barranquilla, Colombia) and COLCIENCIAS (research seeds project - 2013) for financial support for the internship of M. A. Consuegra Peña at the Universitat Autònoma de Barcelona, (Bellaterra, Spain).

The first author highly appreciates Dr. P. Solsona for their support. The technical assistance of the Servei de Microscòpia and the Servei de Difracció de Raigs X of the UAB are greatly appreciated.
To Claudia Rondón for initial grammatical corrections and Juan David Nieto for the edition of the SEM micrographs.

\section{REFERENCES}

Akkouche, K., Guittoum, A., Boukherroub, N. \& Souami, N. (2011). Evolution of structure, microstructure and hyperfine properties of nanocrystalline $\mathrm{Fe}_{50} \mathrm{Co}_{50}$ powders prepared by mechanical alloying. J. Magn. Magn. Mater., 323(21), 2542-2548.

Bergheul, S., Otmane, F. \& Azzaz, M. (2012). Structural and microwave absorption properties of nanostructured $\mathrm{Fe}$-Co alloys. Adv. Powder Technol., 23(5), 580-582.

Chermahini, D., Zandrahimi, M., Shokrollahi, H. \& Sharafi, S. (2009a). The effect of milling time and composition on microstructural and magnetic properties of nanostructured Fe-Co alloys. J. Alloys Compd., 477(1-2), 45-50.

Chermahini, M. D., Sharafi, S., Shokrollahi, H., Zandrahimi, M. \& Shafyei, A. (2009b). The evolution of heating rate on the microstructural and magnetic properties of milled nanostructured $\mathrm{Fe}_{1-\mathrm{x}} \mathrm{Co}_{\mathrm{x}}(\mathrm{x}=0.2,0.3,0.4,0.5$ and 0.7$)$ powders. J. Alloys Compd., 484(1-2), 54-58.

Chermahini, M. D., Rahimipour, M. R. \& Pakseresht, A. H. (2014). Microstructure and magnetic properties of nanostructured $\mathrm{Fe}$-Co powders prepared by series of milling and annealing treatments. Adv. Powder Technol., 25(1), 462-466.

Chitsazan, B., Shokrollahi, H., Behvandi, A. \& Mirzaee, O. (2011). Characterization and magnetic coercivity of nanostructured $\left(\mathrm{Fe}_{50} \mathrm{Co}_{50}\right)_{100-\mathrm{x}} \mathrm{V}_{\mathrm{x}=0,2,4}$ powders containing a small amount of $\mathrm{Co}_{3} \mathrm{~V}$ intermetallic obtained by mechanical alloying. Powder Technol., 214(1), 105-110.

Khajepour, M. \& Sharafi, S. (2011). Structural and magnetic properties of nanostructured $\mathrm{Fe}_{50}\left(\mathrm{Co}_{50}\right)-6.5 \mathrm{wt} \% \mathrm{Si}$ powder prepared by high energy ball milling. J. Alloys Compd., 509(29), 7729-7737.

Lutteroti, L. \& Scardi, P. (1990). Simultaneous structure and size-strain refinement by the Rietveld method. J. Appl. Cryst., 23: 246-252.

Poudyal, N., Rong, C., Zhang, Y., Wang, D., Kramer, M. J., Hebert, R. J. \& Liu, J. (2012). Self-nanoscaling in FeCo alloys prepared via severe plastic deformation. J. Alloys Compd., 521: 55-59. 
Sharifati, A. \& Sharafi, S. (2012). Structural and magnetic properties of nanostructured $\left(\mathrm{Fe}_{70} \mathrm{Co}_{30}\right)_{100-\mathrm{x}} \mathrm{Cu}_{\mathrm{x}}$ alloy prepared by high-energy ball milling. Mater. Design, 41: 8-15.

Shokrollahi, H. (2009). The magnetic and structural properties of the most important alloys of iron produced by mechanical alloying. Mater. Design, 30(9), 3374-3387.

Suryanarayana, C. (2001). Mechanical alloying and milling. Prog. Mater. Sci., 46(1-2), 181-184.

Yepes, N., Orozco, J., Caamaño, Z., Mass, J. \& Pérez, G. (2014). Preparation and characterization of $\mathrm{Fe}_{50} \mathrm{Co}_{50}$ nanostructured alloy. J. Phys.: Conf. Ser., 480(1), 1-4.

Yousefi, M. \& Sharafi, S. (2012). The effect of simultaneous addition of $\mathrm{Si}$ and $\mathrm{Co}$ on microstructure and magnetic properties of nanostructured iron prepared by mechanical alloying. Mater. Design, 37: 325-333.

Zeng, Q., Baker, I., McCreary, V. \& Yan Z. (2007). Soft ferromagnetism in nanostructured mechanical alloying FeCo-based powders. J. Magn. Magn. Mater., 318(1-2), 28-38.

\section{AUTHORS}

\section{Zulia-Isabel Caamaño De Ávila}

Affiliation: Universidad del Atlántico

Bachelor in Education Sciences: Mathematics and

Physics, Universidad del Atlántico

Master in Materials Science, Universitat Autònoma de

Barcelona

Doctorate in Sciences Physics, Universitat Autònoma

de Barcelona

e-mail: zuliacaamano@mail.uniatlantico.edu.co

\section{María-Angélica Consuegra-Peña}

Affiliation: Universidad del Atlántico

BSc. in Physics, Universidad del Atlántico

e-mail: mangie0121@hotmail.com

\section{María-Dolores Baró}

Affiliation: Universitat Autònoma de Barcelona

BSc in Physics, Universitat de Barcelona

Doctorate in Sciences (Physics), Universitat

Autònoma de Barcelona

e-mail: dolors.baro@uab.es

\section{Santiago Suriñach}

Affiliation: Universitat Autònoma de Barcelona

BSc in Physics, Universidad Autónoma de Barcelona

Doctorate in Sciences (Physics), Universitat

Autònoma de Barcelona

e-mail: santiago.surinyach@uab.es 
